\title{
Przeciwdziałanie nielegalnej imigracji do Polski na granicy polsko-ukraińskiej w latach 2009-2019
}

\section{Counteracting Illegal Immigration to Poland on the Polish-Ukrainian Border in 2009-2019}

\section{Abstract}

Illegal migration is one of the most frequently committed border crimes. The cooperation of states and specialized services in the field of combating and counteracting illegal migration is an expression of the implementation of the overriding goal, which is the security of the state and its citizens. As shown by the statistics of the Border Guard, the Polish-Ukrainian border is characterized by the greatest personal traffic. In 2009-2019, most illegal immigration was recorded on this section of the border. The article discusses the scale and scope of the phenomenon of illegal immigration on the Polish-Ukrainian border, and highlights the cooperation of services and organizations competent in this field.

Keywords: illegal migration, cross-border cooperation, cross-border crime, Border Guard, foreigners 


\section{Противодействие незаконной иммиграции в Польшу на польско- украинской границе в 2009-2019 гг.}

\section{Аннотация}

Незаконная миграция является одним из наиболее частых преступлений на границе. Сотрудничество государств и специализированных служб в борьбе с нелегальной миграцией и ее предотвращением выражает важнейшую цель, которая состоит в обеспечении безопасности государства и его граждан. Как показывает статистика Пограничной службы, польско-украинская граница характеризуется наибольшим пассажиропотоком. В 2009-2019 годах на этом пограничном участке было зарегистрировано наибольшее число случаев незаконной иммиграции. В статье обсуждаются масштабы и диапазон нелегальной иммиграции на польско-украинской границе, а также обращается внимание на сотрудничество служб и организаций, компетентных в этой области.

Ключевые слова: нелегальная миграция, трансграничное сотрудничество, трансграничная преступность, пограничная охрана, иностранцы

$I$ migracje jako zjawisko mają wielowymiarowy charakter. Uwarunkowane są sytuacją ekonomiczną, społeczną i polityczną w danym czasie i miejscu. Stały się elementem transnarodowej rewolucji, która zmienia strukturę społeczeństw, jak i życie polityczne na całym globie (Castles, Miller, 2011, s. 24). Dodatkowo procesy globalizacyjne, pogłębiona współpraca między państwami o charakterze gospodarczym, liberalizacja przepisów prawnych w zakresie przekraczania granic oraz rozwój nowoczesnych technologii sprzyjają dynamice i wielkości procesów imigracyjnych.

Imigracja, jej formy i intensywność wymagają od państw, jako głównych podmiotów odpowiedzialnych za regulowanie ruchów ludnościowych, podjęcia odpowiednich działań w sferze prawno-instytucjonalnej. Pogłębiona współpraca regionalna w ramach organizacji międzynarodowych, jak na przykład Unia Europejska, stanowi forum współpracy w zakresie tworzenia efektywnych, humanitarnych i bezpiecznych zasad kontroli granic zewnętrznych państw członkowskich. Należy zaznaczyć, iż pomimo istnienia ponadnarodowych struktur instytucjonalnych to państwa nadal pozostają podstawowym i zasadniczym filarem regulującym procesy imigracyjne. Odpowiedzią na 
zjawisko imigracji międzynarodowych jest przyjęcie określonego modelu polityki imigracyjnej państwa. Polityka ta reguluje warunki wjazdu, pobytu i wyjazdu cudzoziemców z terytorium państwa. Ponadto formułuje prawa i obowiązki państwa wobec cudzoziemców oraz cudzoziemców wobec państwa przyjmującego. Kształtuje system instytucjonalny w zakresie legalizacji pobytu i zatrudniania, opieki nad imigrantami oraz zapobiegania nielegalnej imigracji. Polityka imigracyjna jest specyficznym rodzajem aktywności państwa, ponieważ dotyczy suwerennych prerogatyw, dziedzin mających kluczowe znaczenie dla sfery bezpieczeństwa obywateli (Okólski, 1998, s. 4).Zakres przedmiotowy polityki imigracyjnej obejmuje szeroko pojęte działania dotyczące imigracji, a na jej ogólny charakter składają się polityki sektorowe.

W opublikowanym w 2013 roku raporcie Organizacji Narodów Zjednoczonych, zatytułowanym International Migration Policies: Government Views and Priorities wskazano polityki szczegółowe zajmujące się kwestią migracji międzynarodowych. Jedną z nich jest działalność z zakresu nieuregulowanej i nielegalnej imigracji, a więc katalogu działań podejmowanych przez państwo w celu ograniczenia nielegalnej imigracji, nadania określonego statusu cudzoziemcom. W tym obszarze znajduje się również polityka azylowa i uchodźcza (ONZ, 2013). Większość imigracji ma charakter legalny, co oznacza, że odbywa się zgodnie z obowiązującymi przepisami prawnymi, jednakże zdarzają się sytuacje w których dochodzi do świadomego złamania przepisów prawa $\mathrm{w}$ celach przedostania się na terytorium innego państwa. D. Abraham stwierdza, iż mimo ponadnarodowych działań na rzecz nielegalnej imigracji, w tym tworzenia wyspecjalizowanych agencji, jak np. Frontex w UE, zarządzanie i rzeczywista kontrola nad granicami jest wyrazem realnej państwowości i przedłużeniem spraw zagranicznych państwa (Abraham, 2015, s. 291). Państwo podejmuje wysiłek za pomocą dostępnych instrumentów i środków, aby skutecznie przeciwdziałać nielegalnej imigracji. Celem artykułu jest zaprezentowanie skali nielegalnej imigracji na granicy polsko-ukraińskiej, jej dynamiki i zmian w oparciu o statystyki Straży Granicznej oraz raporty Ministerstwa Spraw Wewnętrznych i Administracji, publikowane w latach 2009-2019. Ponadto zostaną wskazane podstawy prawne współpracy Polski i Ukrainy oraz formy współpracy instytucjonalnej w zakresie zwalczania nielegalnej imigracji. W artykule wykorzystano metodę statystyczną, komparatystyczną oraz dedukcję. 
Na początku warto zaznaczyć, że w okresie ostatnich kilkudziesięciu lat, Polska stała się państwem atrakcyjnym dla imigrantów zza wschodniej granicy. Uważana za lidera przemian gospodarczych w Europie Środkowo-Wschodniej jawi się jako miejsce poprawy warunków bytowych, zwłaszcza dla obywateli państw wschodnioeuropejskich. Wśród czynników, które determinują wspomniany wizerunek Polski, należy wskazać:

- przemiany gospodarcze, sytuujące polską gospodarkę jako konkurencyjną względem innych;

- liberalizację przepisów prawa w zakresie zatrudniania i pobytu cudzoziemców;

- bliskość geograficzną i kulturową;

- stosunkowo niskie koszty utrzymania w porównaniu do państw Europy Zachodniej;

- członkostwo Polski w Unii Europejskiej i w strefie Schengen;

- ustabilizowaną sytuację mniejszości cudzoziemskich;

- wolność polityczną, wyznaniową i obyczajową.

Przedstawione czynniki nie powinny być traktowane jako wyczerpujące.

Przystępując do Unii Europejskiej, granica wschodnia Polski stała się granicą zewnętrzną UE. Dlatego też kwestie bezpieczeństwa i przeciwdziałania nielegalnej imigracji mają znaczenie nie tylko dla Polski, ale także dla Unii Europejskiej. Ponadto uczestnictwo w strefie Schengen obliguje władze do podjęcia efektywnych działań na rzecz przeciwdziałania nielegalnej imigracji. Impulsem, który implikuje rozwijanie ściślejszej współpracy na rzecz ochrony granic, jest bezpośrednie sąsiedztwo Polski z Ukrainą, która od 2014 roku w wyniku aneksji Krymu nieustannie zmaga się z separatyzmem i wojną w Donbasie oraz destabilizacją życia społecznego na tym obszarze. Ewentualna eskalacja konfliktu w przyszłości może skutkować wzrostem masowej imigracji do Polski.

\section{Nielegalna imigracja - charakterystyka zjawiska}

Dostęp do rynku pracy, świadczeń socjalnych oraz ochrona przed niepożądanymi imigrantami regulowane są poprzez politykę imigracyjną. Służą temu instrumenty prawne, określające warunki, jakie musi spełnić cudzoziemiec, aby móc legalnie przebywać i pracować w państwie pobytu. Imigracja ma 
charakter nielegalny gdy stoi w sprzeczności z obowiązującym prawem, a sam czyn jest penalizowany. Imigracje nielegalne określane są także mianem „nieudokumentowanych", bowiem określają zjawisko, które w wielu przypadkach pozostaje nierejestrowane. Ponadto dotyczą sytuacji, gdy osoba nie posiada dokumentów lub upłynie termin ich ważności (Klaus, Szulecka, 2018, s. 368).

Pojęcie nielegalnej imigracji najczęściej rozumiane jest jako pobyt cudzoziemca wbrew obowiązującym w danym kraju normom prawnym, które regulują wjazd i/lub pobyt w nim (Lubiewski, 2016, s. 44). Nielegalne przedostanie się na terytorium innego państwa może odbywać się drogą lądową, morską lub powietrzną za pomocą sfałszowanych dokumentów lub bez nich. Wielkość i intensywność zjawiska nielegalnej imigracji jest determinowana wieloma zmiennymi czynnikami, do których należy zaliczyć: zagrożenie życia i zdrowia, prześladowania ze względu na religię, poglądy polityczne lub pochodzenie etniczne, konflikty zbrojne oraz procesy globalizacyjne (Suduł, 2012-2013, s. 374). Czynniki te obejmują zatem wszystko, co motywuje cudzoziemca do podjęcia decyzji m.in. o nielegalnym przedostaniu się przez granicę państwową, pozostawaniu na terenie państwa pobytu po upływie ważności dokumentów lub podejmowania pracy nielegalnie.

Polskie ustawodawstwo nie określa wprost zagadnienia nielegalnej imigracji - nie podaje definicji legalnej. Określa konsekwencje nielegalnego przekroczenia granicy lub nielegalnego pobytu na terytorium Polski. Należy wskazać na dwa obszary analizowanego zagadnienia. Pierwszy, który odnosi się do niezgodnego z prawem wjazdu na terytorium Polski oraz drugi, dotyczący kwestii administracyjnych określających warunki, które cudzoziemiec musi spełnić, aby móc przebywać legalnie w Polsce (Lubiewski, 2016, s. 45-46). Kwestię nielegalnej imigracji można rozumieć dwojako. Z jednej strony, przez pryzmat nielegalnego przekroczenia granicy. $Z$ drugiej strony, nielegalna imigracja może wiązać się z legalnym przekroczeniem granicy, ale nielegalnym pobytem $\mathrm{w}$ państwie pobytu, w związku $\mathrm{z}$ utratą ważności dokumentów uprawniających do przebywania na jego terytorium. Nielegalna imigracja dokonywana jest zarówno przez pojedyncze osoby, jak i przez grupy osób.

Nielegalna imigracja jako forma przestępczości granicznej, tj. przestępstw związanych z przemieszczaniem się podmiotów i przedmiotów przez granicę (Mikołajczyk, 1999, s. 78), implikuje powstawanie kolejnych negatywnych 
zjawisk. Przyczynia się do rozwoju grup przemytniczych, fałszerstw dokumentów, wzrostu żebractwa i prostytucji oraz rozrostu szarej strefy zatrudnienia w państwie docelowym.

W rozwój nielegalnej imigracji niejednokrotnie zaangażowane są grupy przestępcze, które oferują odpłatnie usługi przemytu cudzoziemców przez granicę. Grupy te, mające zazwyczaj charakter transgraniczny, organizują środki transportu, schronienie na czas przerzutu, oferują podrobione dokumenty (Kaczmarczyk, 2015, s. 10). Należy rozróżnić indywidualne oraz zorganizowane formy przekraczania granicy. Pierwsza, indywidualna, dotyczy sytuacji, gdy imigrant własnymi siłami próbuje przedostać się w sposób nielegalny przez granicę, często nie posiadając zaplecza technicznego umożliwiającego jej przekroczenie. Druga forma odnosi się do skorzystania z usług wyspecjalizowanych grup przestępczych, gdzie rola samego zainteresowanego sprowadza się do opłacenia działań i wykonywania poleceń przemytników. Przerzut jest swoistą formą uzależnienia imigranta od przemytników, gdyż po dotarciu do celu przemytnicy nadal czerpią korzyści z nielegalnej pracy cudzoziemca. W przypadku przemytu działanie ogranicza się do ułatwienia pomocy przy przekraczaniu granicy. Procederem towarzyszącym przemytowi jest przemyt kontrabandy, m.in. papierosów, alkoholu, narkotyków czy dzikich zwierząt (Suduł, 2012-2013, s. 379).

Skala nielegalnej imigracji jest trudna do oszacowania. Dzieje się tak, ponieważ:

- zjawisko nielegalnej imigracji ma charakter nieudokumentowany, zatem trudno jest oszacować dokładną skalę zjawiska;

- często brakuje możliwości zastosowania oficjalnych metod pomiaru i zbierania informacji w zakresie nielegalnej imigracji, zwłaszcza w strefie Schengen;

- osoby, którym nie udało się przekroczyć granicy, mogą podjąć kolejną próbę, aż do skutku;

- współpraca z podmiotami i pracodawcami, którzy czerpią korzyści z pracy nielegalnych imigrantów, pozostaje utrudniona (Lubiewski, 2016, s. 63).

Problem nielegalnej imigracji do Polski jest tym bardziej istotny, bowiem od 2004 roku jest ona państwem granicznym Unii Europejskiej. Przystąpienie do strefy Schengen uatrakcyjniło jej położenie jako terytorium tranzytowego 
dla obywateli państw Europy Wschodniej. Polska jest położona na szlaku wschodnioeuropejskim migracji. Dla przykładu, jak podaje Frontex, w 2016 roku 25\% ogółu wszystkich wykryć nielegalnego przekroczenia wschodniej granicy zewnętrznej UE dotyczyło obywateli z krajów sąsiednich, głównie Ukraińców, Rosjan oraz w mniejszym stopniu z Białorusi i Mołdawii. Większość z nich przekroczyła lądową granicę Polski i Rumunii z Ukrainą (Frontex 2020).

Odcinkiem narażonym na przemyt nielegalnych imigrantów do UE jest granica wschodnia Polski z Ukrainą, Białorusią oraz Rosją. Dane statystyczne gromadzone przez Straż Graniczną stanowią obecnie największe źródło informacji o analizowanym zjawisku. Nielegalna imigracja jest najczęściej popełnianym przestępstwem granicznym, zwłaszcza w zorganizowanej formie. Raport o stanie bezpieczeństwa państwa z 2016 roku wymienia szlaki przerzutu nielegalnych imigrantów (MSWiA, 2017, s. 98):

- Rosja - Estonia - Łotwa - Litwa - Polska - pozostałe kraje Europy Zachodniej (tzw. szlak nadbałtycki);

- Rosja - Ukraina/Białoruś - Polska - Niemcy - pozostałe kraje Europy Zachodniej;

- Syria i Irak - Turcja - Grecja - Macedonia - Serbia - Chorwacja Węgry - Austria - Słowacja - Czechy - Polska i dalej do Niemiec, Szwecji lub Finlandii (tzw. szlak bałkański).

Coroczne raporty o stanie bezpieczeństwa w Polsce publikowane przez Ministerstwo Spraw Wewnętrznych i Administracji wymieniają główne formy przestępczości granicznej. Jednym z nich jest imigracja nielegalna, jaki i quasi-legalna, która polega na nadużywaniu oficjalnych sposobów wjazdu na teren Polski. W tym kontekście terytorium Polski jest traktowane jako przestrzeń tranzytowa, umożliwiająca wjazd na teren UE. Bliskość geograficzna Polski, zwłaszcza dla obywateli państw Europy Wschodniej i Azji sprzyja nielegalnej imigracji. W obszarze przestępczości transgranicznej związanej z nielegalną imigracją raporty MSWiA z lat 2009-2016 wskazują na czynniki, które sprzyjają nielegalnej imigracji. Należą do nich ${ }^{1}$ :

1 Każdy z raportów zawiera listę czynników co do sposobów i form nielegalnej imigracji, która jest corocznie aktualizowana (Raporty o stanie bezpieczeństwa w Polsce $\mathrm{z}$ lat 2009-2016, Ministerstwo Spraw Wewnętrznych i Administracji. 
- utrudniona identyfikacja cudzoziemców ze względu na ich podobieństwo antropomorficzne, umożliwiające m.in. wykorzystywanie tych samych dokumentów tożsamości/pobytowych przez różne osoby; wykorzystywanie metody na podobieństwo tzw. 'look alike';

- handel dowodami tożsamości, dokonywany przez obywateli państw członkowskich Unii Europejskiej;

- wykorzystywanie nowoczesnych technologii do wytworzenia oraz nabycia dokumentów uprawniających do przekroczenia granicy;

- nadużywanie procedur w zakresie nadawania azylu oraz statusu uchodźcy;

- wykorzystywanie przepisów prawnych umożliwiających wjazd na teren RP pod pretekstem podejmowania nauki, pracy, w celach turystycznych, biznesowych, kulturalnych, przez wykorzystanie fałszywych lub poświadczających nieprawdę dokumentów uprawniających do otrzymania stosownej wizy;

- przerzut imigrantów w zamkniętych przestrzeniach ładunkowych pojazdów;

- uzyskiwanie prawa pobytu za pomocą fikcyjnych małżeństw.

Nowe formy i sposoby nielegalnej imigracji wynikają m.in. ze zmian prawnych w zakresie dostępu do rynku pracy, legalizacji pobytu, instrumentów prawnych i instytucjonalnych wykorzystywanych $\mathrm{w}$ walce $\mathrm{z}$ tym procederem. Przedstawione czynniki ewoluują i dostosowywane są do bieżącej sytuacji.

\section{Prawne podstawy współpracy Polski i Ukrainy w zakresie ochrony granic i przeciwdziałania nielegalnej imigracji}

Granica polsko-ukraińska istnieje od 1991 roku, kiedy to Ukraina formalnie uzyskała niepodległość i jest trzecią co do długości granicą z sąsiadującymi państwami. Natomiast wschodnia granica Polski, będąca granicą zewnętrzną UE, wynosi 1580,77 km, z czego odcinek polsko-ukraiński ma długość 535,18 $\mathrm{km}$.

Granica polsko-ukraińska została ujęta w Traktacie między Rzecząpospolitą Polską a Ukrainą o dobrym sąsiedztwie, przyjaznych stosunkach i współpracy z 18 maja 1992 roku (Dz.U.1993 r., Nr 125, poz. 573). Traktat zawiera 
zapisy dotyczące pogłębiania współpracy transgranicznej, bezpieczeństwa, zwiększenia liczby przejść granicznych oraz działań na rzecz efektywnej kontroli celnej i granicznej. Polska i Ukraina zobowiązały się do współdziałania w zwalczaniu przestępczości zorganizowanej, narkotykowej, terroryzmu, przestępczości gospodarczej, nielegalnego handlu dziełami sztuki, przemytu, a także innych rodzajów przestępczości.

Kolejnym dokumentem regulującym kwestie graniczne jest Umowa między Rzeczpospolitą a Ukrainą o stosunkach prawnych na polsko-ukraińskiej granicy państwowej oraz wzajemnej pomocy państwowej oraz współpracy i wzajemnej pomocy w sprawach granicznych, sporządzona w Kijowie 12 stycznia 1993 roku (Dz.U. z 1994 r., Nr 63, poz. 267). W swym przedmiocie umowa uregulowała zagadnienia dotyczące potwierdzenia przebiegu linii granicy państwowej pomiędzy oboma państwami, które zostały ustalone pomiędzy Polską a Związkiem Socjalistycznych Republik Radzieckich jeszcze w 1945 oraz 1951 roku. Zawiera regulacje techniczne i infrastrukturalne dotyczące oznakowania i utrzymania granicy. Umowa umożliwia powołanie pełnomocników granicznych, reguluje zakres ich praw i obowiązków oraz stwarza możliwość utworzenia Komisji Granicznej. W art. 36 zobowiązano strony umowy do podejmowania stosownych przedsięwzięć zapobiegających nielegalnemu przedostaniu się przez granicę oraz wymiany informacji w tym zakresie. Pełnomocnicy graniczni zostali wyposażeni w odpowiednie kompetencje do współpracy granicznej, m.in.: oceny stanu ochrony granicy państwowej; koordynowania służby ochrony granicy; rozpatrywania i prowadzenia postępowań wyjaśniających oraz rozstrzygania wszystkich zdarzeń nielegalnego przekraczania granicy państwowej; nielegalnego podpłynięcia, nielegalnego przelotu przez granicę państwową oraz nielegalnego kontaktowania się przez granicę państwową. Umowa o stosunkach prawnych na polsko-ukraińskiej granicy państwowej oraz wzajemnej pomocy państwowej, oraz współpracy i wzajemnej pomocy w sprawach granicznych została zawarta na 10 lat. Po tym czasie umowa automatycznie ulega przedłużeniu o kolejne 5 lat, jeżeli żadna ze stron na rok przed upływem terminu obowiązywania nie wypowiedziała umowy w drodze notyfikacji.

Do aktów prawnych, które mają znaczenie dla granicy polsko-ukraińskiej, należy zaliczyć Umowę sporządzoną w Warszawie dnia 18 maja 1992 roku między Rządem Rzeczypospolitej Polskiej a Rządem Ukrainy w sprawie 
przejść granicznych (M.P. z 2003 r., Nr 37, poz. 530). Dokument uregulował lokalizację przejeść granicznych, przez które ma odbywać się ruch graniczny drogowy i kolejowy. Ponadto, Polska i Ukraina w kolejnych latach zawarły szereg aktów prawnych w sprawie utworzenia kolejnych przejść granicznych.

Warto także wskazać na Umowę między Rządem Rzeczypospolitej Polskiej a Rządem Ukrainy o współpracy w zakresie zwalczania przestępczości zorganizowanej (Dz.U. z 2004 r., Nr 38, poz. 343), podpisaną w Kijowie 3 marca 1999 roku. Strony umowy zobowiązały się do współpracy między organami właściwymi w sprawach bezpieczeństwa i porządku publicznego, dotyczącej zapobiegania i zwalczania przestępczości zorganizowanej oraz ujawniania sprawców przestępstw, a w szczególności nielegalnej imigracji, handlu ludźmi oraz fałszowania dokumentów urzędowych. Art. 6 umowy precyzuje, że w celu zwalczania nielegalnej imigracji i zapobieganiu przemytowi ludzi strony będą przekazywać sobie informacje, w tym informacje o organizatorach nielegalnych imigracji, wzorach dokumentów i pieczęci uprawniających do przekraczania granicy państwowej oraz rodzajach wiz i symboli.

Wielu cudzoziemców nie legalizuje swojego pobytu w Polsce. Zgodnie z procedurami Konwencji Dublin II, zastąpionej w 2013 roku rozporządzeniem Dublin III (Dz.U. UE z 2013 r., L 180/31) osoby, które złożą wniosek pobytowy w Polsce, a znajdują się w innym państwie, w przypadku kontroli legalności pobytu zgodnie z przepisami są odsyłane do kraju, w którym złożyły wniosek po raz pierwszy. W tym kontekście należy wskazać na Umowę o readmisji między Wspólnotą Europejską a Ukrainą, podpisaną w 2007 roku (Dz.U. z 2007 r., L 332/48), oraz Protokół Wykonawczy między Rządem Rzeczpospolitej Polskiej a Gabinetem Ministrów Ukrainy do Umowy o readmisji między Wspólnotą Europejską a Ukrainą, sporządzonej w Luksemburgu dnia 18 czerwca 2007 roku, który podpisano 24 kwietnia 2017 r. w Warszawie (Dz.U. z 2019 r., poz. 48). W protokole wskazano podmioty odpowiedzialne za wykonywanie postanowień umowy, właściwość organów rozpatrujących wnioski wraz z właściwymi procedurami w zakresie readmisji. Ponadto protokół wymienia przejścia graniczne wykorzystywane do procedury readmisji oraz szczególne przypadki wymagające podjęcia dodatkowych środków w celu zapewnienia właściwego wykonania wspomnianej procedury. 


\section{Przeciwdziałanie nielegalnej imigracji na granicy polsko-ukraińskiej}

Zapewnienie bezpieczeństwa obywateli jest jednym z nadrzędnych celów działalności państwa, bowiem odnosi się do sfery egzystencjalnej jego funkcjonowania. Położenie geograficzne sytuuje Polskę jako państwo frontowe w zakresie walki z nielegalną imigracją. Ponadto zniesienie kontroli granicznych wewnątrz strefy Schengen daje możliwość swobodnego poruszania się po państwach członkowskich strefy, co sprzyja nielegalnej imigracji i próbom przedostania się do państwa docelowego. Formułowanie działań krajowych, których celem jest ograniczenie nielegalnej imigracji, realizowane jest w oparciu o unijną politykę imigracyjną. Synchronizacja działań krajowych z unijną polityką bezpieczeństwa jest wyrazem realizacji wspólnotowego zarządzania granicami (Kacperska, Kacprzak, Kmieć, Król, Łukasiewicz, 2019, s. 132).

Europejska Agencja Straży Granicznej i Przybrzeżnej² wskazuje, że nielegalna imigracja na odcinku wschodniej granicy UE jest znacznie mniejsza w stosunku do innych szlaków imigracyjnych, a ruch osobowy dotyczy głównie obywateli Europy Wschodniej. Większość problemów, zdaniem Agencji, wiąże się z przemytem wyrobów akcyzowych na małą skalę (Frontex, 2020). Potwierdzają to także statystyki publikowane przez polską Straż Graniczną.

Tabela 1. Osoby ruch graniczny w latach 2009-2019 na granicy wschodniej Polski

\begin{tabular}{|c|c|c|c|c|}
\hline $\begin{array}{c}\text { Granica } \\
\text { rok }\end{array}$ & $\begin{array}{c}\text { Granica } \\
\text { polsko-rosyjska }\end{array}$ & $\begin{array}{c}\text { Granica } \\
\text { polsko-białoruska }\end{array}$ & $\begin{array}{c}\text { Granica } \\
\text { polsko-ukraińska }\end{array}$ & $\begin{array}{l}\text { Granica zewnętrz- } \\
\text { na UE obejmująca } \\
\text { terytorium Polski }\end{array}$ \\
\hline 2009 & 1276339 & 5923569 & 11666322 & 27647428 \\
\hline 2010 & 1451492 & 7258821 & 13064958 & 30639967 \\
\hline 2011 & 2373517 & 8245954 & 13870528 & 33300130 \\
\hline 2012 & 4073142 & 8800591 & 15039698 & 37540297 \\
\hline 2013 & 6188605 & 8808734 & 16765792 & 41933324 \\
\hline 2014 & 6565325 & 8817678 & 17704835 & 43547675 \\
\hline 2015 & 6098860 & 7817371 & 21114730 & 46267157 \\
\hline 2016 & 2292820 & 7090950 & 22634438 & 47551999 \\
\hline
\end{tabular}

2 Dawniej: Europejska Agencja Zarządzania Współpracą Operacyjną na Zewnętrznych Granicach Państw Członkowskich Unii Europejskiej - Frontex. 


\begin{tabular}{|l|c|c|c|c|}
\hline $\begin{array}{c}\text { Granica } \\
\text { rok }\end{array}$ & $\begin{array}{c}\text { Granica } \\
\text { polsko-rosyjska }\end{array}$ & $\begin{array}{c}\text { Granica } \\
\text { polsko-białoruska }\end{array}$ & $\begin{array}{c}\text { Granica } \\
\text { polsko-ukraińska }\end{array}$ & $\begin{array}{c}\text { Granica zewnętrz- } \\
\text { na UE obejmująca } \\
\text { terytorium Polski }\end{array}$ \\
\hline 2017 & 2524520 & 8269087 & $\mathbf{2 2 ~ 8 5 3 6 8 8}$ & 51008705 \\
\hline 2018 & 3534899 & 8955437 & $\mathbf{2 1 5 8 6 7 5 3}$ & 52291128 \\
\hline 2019 & 3466814 & 8814753 & $\mathbf{2 1 7 3 7 6 6 6}$ & 54391942 \\
\hline
\end{tabular}

Źródło: opracowanie własne na podstawie statystyk KG SG dla lat 2009-2019.

Z danych zamieszczonych w tabeli 1 wynika, że ruch osobowy na granicy wschodniej Polski systematycznie wzrasta. W 2009 roku granicę wschodnią przekroczyło ponad 27,6 mln osób. Z kolei w 2019 roku liczba ta osiągnęła niemalże 54, 4 mln osób. Oznacza to, że w ciągu 10 lat liczba przekraczających wschodnią granicę Polski uległa podwojeniu. Spośród wszystkich odcinków granicznych pomiędzy Polską a Rosją, Białorusią i Ukrainą, granicą o największym ruchu osobowym jest granica polsko-ukraińska. Podobnie jak w przypadku ogólnej liczby osób przekraczających wschodnią granicę, tak w przypadku polsko-ukraińskiej granicy liczba ta wzrosła dwukrotnie. W 2017 roku odnotowano największy ruch graniczny, który wyniósł ponad 22,8 mln osób. W kolejnych latach nastąpił spadek - 21,6 mln w 2018 roku i 21,7 mln w 2019 roku. Najczęstszą przyczyną przekraczania granicy wbrew przepisom jest brak ważnej wizy lub dokumentów pobytowych. W 2016 roku liczba osób zatrzymanych za przekroczenie lub usiłowanie przekroczenia granicy na podstawie fałszywego dokumentu, w tym także dokumentu wyłudzonego, stanowiła 33\% ogółu zatrzymanych na granicach Polski. Druga najbardziej rozpowszechniona metoda nielegalnego przekroczenia granicy to brak dokumentów, co stanowiło około $20 \%$ ogółu zatrzymanych (MSWiA, 2017, s. 100). Tabela 2 przedstawia liczbę osób zatrzymanych na granicy wschodniej przez Straż Graniczną, którzy przekroczyli lub usiłowali przekroczyć granicę państwową wbrew przepisom.

Cudzoziemcy, którzy nie spełniają warunków wjazdu, nie mogą przekroczyć granicy Rzeczypospolitej Polskiej. Wówczas alternatywą przedostania się na docelowe terytorium jest przekroczenie granicy w niedozwolonym miejscu lub na podstawie fałszywych dokumentów lub też dokumentów, które nie uprawniają do przekraczania granicy. Odsetek osób zatrzymanych 
Tabela 2. Liczba osób zatrzymanych którzy przekroczyli lub usiłowali przekroczyć granicę państwową wbrew przepisom przez Straż Graniczną w latach 2009-2019

\begin{tabular}{|l|c|c|c|c|}
\hline $\begin{array}{l}\text { Gra- } \\
\text { nica } \\
\text { rok }\end{array}$ & $\begin{array}{l}\text { Granica polsko-ro- } \\
\text { syjska }\end{array}$ & $\begin{array}{l}\text { Granica polsko- } \\
\text {-białoruska }\end{array}$ & $\begin{array}{l}\text { Granica polsko- } \\
\text {-ukrainska }\end{array}$ & $\begin{array}{l}\text { Granica } \\
\text { zewnętrzna } \\
\text { UE obejmująca } \\
\text { terytorium Polski }\end{array}$ \\
\hline 2009 & 152 & 209 & $\mathbf{8 9 5}$ & 1407 \\
\hline 2010 & 34 & 143 & $\mathbf{9 2 4}$ & 1192 \\
\hline 2011 & 47 & 196 & $\mathbf{7 5 8}$ & 1175 \\
\hline 2012 & 16 & 447 & $\mathbf{7 2 2}$ & 1489 \\
\hline 2013 & 89 & 431 & $\mathbf{8 7 6}$ & 1656 \\
\hline 2014 & 99 & 319 & $\mathbf{1 0 8 2}$ & 1788 \\
\hline 2015 & 122 & 367 & $\mathbf{2 1 1 2}$ & 2958 \\
\hline 2016 & 229 & 295 & $\mathbf{1 9 5 5}$ & 2898 \\
\hline 2017 & 333 & 267 & $\mathbf{1 5 4 5}$ & 2538 \\
\hline 2018 & 219 & 342 & $\mathbf{9 8 3}$ & 1991 \\
\hline 2019 & 125 & 201 & $\mathbf{1 0 6 4}$ & 2105 \\
\hline
\end{tabular}

Źródło: opracowanie własne na podstawie statystyk KG SG dla lat 2009-2019.

za nielegalne przekroczenie granicy w stosunku do osób przekraczających wschodnią granicę zewnętrzną UE na polskim odcinku jest znikomy, stanowi niespełna $1 \%$ ogółu. Niemniej granica polsko-ukraińska jest granicą, na której Straż Graniczna odnotowuje najwięcej przypadków nielegalnego przekroczenia granicy. Z jednej strony, można wyprowadzić wniosek, iż liczba ta jest konsekwencją największego wschodniego ruchu granicznego spośród odcinków granicznych z Białorusią i Rosją. Z drugiej strony, po 2015 roku zauważalny jest spadek liczby osób zatrzymywanych na granicy polsko-ukraińskiej, pomimo że liczba osób przekraczających tę granicę w latach 2015-2019 była najwyższa w analizowanym okresie. Wbrew obawom wynikającym $\mathrm{z}$ aneksji Krymu i konfliktu we wschodniej Ukrainie wydarzenia te nie przyczyniły się do gwałtownego wzrostu liczby nielegalnych imigrantów. Niemniej ewentualna eskalacja wspomnianego konfliktu może spowodować gwałtowny wzrost liczby osób próbujących nielegalnie przekroczyć granicę.

Instrumentem polityki imigracyjnej, z którego mogą korzystać służby graniczne w procesie ochrony przed niepożądanymi imigrantami w Polsce, 
jest instytucja odmowy wjazdu oraz wydalenia z terytorium RP. Odmowa wjazdu została zawarta w art. 13 kodeksu granicznego Schengen (Dz.U.UE z 2006 r., L 105/1). Z kolei ustawa z dnia 12 grudnia 2013 roku o cudzoziemcach (Dz.U. z 2013r., poz. 1650 z poźn. zm.) powtórzyła przesłanki kodeksu granicznego, rozszerzając je o kolejne dwie. Ustawa wylicza enumeratywnie sytuacje, w których cudzoziemcowi można odmówić wjazdu na terytorium Rzeczypospolitej. Zgodnie z art. 28 ust. 1 ustawy o cudzoziemcach decyzja o odmowie ma miejsce m.in. w przypadku: braku ważnego dokumentu podróży, ważnej wizy; gdy cudzoziemiec wykorzystał dopuszczalny okres pobytu na terytorium państw obszaru Schengen; cudzoziemiec nie posiada wystarczających środków finansowych w odniesieniu do długości i celu podróży; nie przedstawił dokumentów wystarczających do potwierdzenia celu i warunków planowanego pobytu; figuruje w wykazie osób niepożądanych; jego wjazd mógłby zagrozić bezpieczeństwu i porządkowi publicznemu. W ciągu 10 lat decyzja o odmowie wjazdu została wydana przez polskie służby 553241 razy na granicy zewnętrznej i wewnętrznej Unii (Urząd do Spraw Cudzoziemców, 2020). Wzrost liczby decyzji o odmowie wjazdu w latach 2009-2019 ma charakter nieregularny. W 2010 roku wydano 26941 decyzji o odmowie. Najwięcej decyzji wydano w 2016 roku, wówczas liczba osiągnęła 103 986, dla porównania rok wcześniej tylko 41580 razy, co stanowi niemalże 40\% decyzji o odmowie wjazdu z 2016 roku. Natomiast w 2019 roku przedmiotową decyzję wobec obcokrajowców wydano 95735 razy. Wśród obywateli, którym najczęściej wydawano decyzję o odmowie wjazdu, byli bezpośredni sąsiedzi Polski: Białorusini, Rosjanie i Ukraińcy, ponadto obywatele Gruzji. Spośród wszystkich narodowości w latach 2009-2019 obywatelom Ukrainy najczęściej odmawiano wjazdu na terytorium Polski. W 2019 roku stanowili 60\% ogółu wszystkich cudzoziemców, w stosunku do których wydano decyzję o odmowie wjazdu³.

Nielegalna imigracja sprzyja funkcjonowaniu transgranicznych grup przestępczych. Nielegalni imigranci korzystający z usług przestępców stanowią istotne źródło dochodu dla działalności przestępczej. Funkcjonowanie tychże grup ma charakter ewolucyjny, zależy od warunków i rozwiązań

3 Obliczenia własne na podstawie zestawień rocznych publikowanych przez Urząd do Spraw Cudzoziemców. 
prawnych, sytuacji wewnętrznej państwa i jej znaczenia dla imigracji, a także skali zainteresowania nielegalnym przekroczeniem granicy. Jednym z obszarów działalności grup przestępczych jest handel ludźmi. Polska jako państwo graniczne Unii Europejskiej traktowana jest głównie jako terytorium tranzytowe, choć w wielu przypadkach także jako miejsce docelowe, zwłaszcza dla kobiet - ofiar handlu ludźmi, pochodzących z krajów byłego ZSRR i innych krajów Europy Południowej i Wschodniej (MSWiA, 2011, s. 110). Tylko w 2018 roku Straż Graniczna ujawniła 61 ofiar handlu ludźmi. Ofiarami byli głównie Ukraińcy, Białorusini i Polacy. Pozostali cudzoziemcy pochodzili z Filipin, Wietnamu, Gambii czy Gwinei. W porównaniu z 2017 rokiem, w którym ujawniono 43 osoby, nastąpił wzrost o ponad $40 \%$ w zestawieniu pozytywnych identyfikacji ofiar handlu ludźmi, przeprowadzonych przez służby (Straż Graniczna, 2019). Do najczęstszych form wyzysku ofiar handlu ludźmi należą: prostytucja, praca przymusowa (w tym niewolnictwo domowe), żebranie, kradzieże oraz wyłudzanie kredytów i świadczeń socjalnych ${ }^{4}$.

Ochrona granic i przeciwdziałanie nielegalnej imigracji wymagają współdziałania szeregu instytucji i służb. Realizacja zadań w tym zakresie dotyczy kontroli legalności wjazdu oraz legalności pobytu cudzoziemców. Wśród podmiotów, które bezpośrednio realizują w Polsce przedmiotowe zadania należy wskazać Straż Graniczną, Krajową Administrację Skarbową ${ }^{5}$ - dawniej Służbę Celną oraz Policję. Realizują one zadnia zgodnie z kompetencjami nadanymi przez akty prawne w sposób indywidualny, tj. zadania realizowane tylko przez jedną ze służb oraz w ramach współpracy z innymi podmiotami.

Funkcjonariusze Krajowej Administracji Skarbowej przeprowadzają kontrole w zakresie legalności wwożonych i wywożonych towarów, rozpoznają, zapobiegają i wykrywają sprawców przestępstw skarbowych oraz członków grup przemytniczych. Do zakresu działań należy także przeprowadzanie kontroli legalności zatrudnienia imigrantów i prowadzonej przez cudzoziemców działalności gospodarczej. W ramach współpracy funkcjonariuszy

\footnotetext{
4 Raporty o stanie bezpieczeństwa w Polsce w latach 2009-2016, Ministerstwo Spraw Wewnętrznych i Administracji.

5 Krajowa Administracja Skarbowa powstała na mocy ustawy z dnia 16 listopada 2016 r. o Krajowej Administracji Skarbowej, Dz. U. 2016 poz. 1947.
} 
Krajowej Administracji Skarbowej i Straży Granicznej podejmowane są wspólne patrole i kontrole graniczne.

Policja w zakresie bezpośredniej ochrony granicy państwowej współpracuje ściśle ze Strażą Graniczną. Są to głównie czynności prewencyjne, polegające na wspólnym patrolowaniu dróg prowadzących do granicy państwa oraz działaniach granicznych zmierzających do zatrzymania sprawców przekraczających granicę wbrew przepisom. Do wspólnych działań obu służb należy zaliczyć także przeszukiwania posesji, targowisk, dworców kolejowych i autobusowych, hoteli pod kątem nielegalnego pobytu imigrantów, ponadto kontrolę pojazdów i osób wjeżdżających do Polski. W strukturze Policji funkcjonuje Centralne Biuro Śledcze Policji jako jednostka organizacyjna realizująca na obszarze całego kraju zadania w zakresie rozpoznawania, zapobiegania i zwalczania przestępczości zorganizowanej. Do głównych działań CBŚP należy m.in.: planowanie, koordynowanie i podejmowanie działań ukierunkowanych na rozpoznawanie i zwalczanie przestępczości zorganizowanej krajowej i międzynarodowej; wykonywanie analiz kryminalnych i prowadzenie zbiorów danych wykorzystywanych przy realizacji właściwych zadań; prowadzenie czynności wykrywczych w sprawach przestępstw uprowadzeń osób dla okupu w kraju i poza jego granicami oraz nadzorowanie, koordynowanie i wspieranie tych czynności, prowadzonych przez jednostki organizacyjne Policji ${ }^{6}$.

Kluczowe zadanie w zakresie przeciwdziałania nielegalnej imigracji posiada Straż Graniczna. Na podstawie uprawnień ustawowych ta umundurowana formacja poza kontrolami granicznymi realizuje także kontrole legalności pobytu i zatrudnienia. Zadania z zakresu przeciwdziałania nielegalnej imigracji zostały ujęte w ustawie z dnia 12 października 1990 roku o Straży Granicznej (Dz.U.z 2020 r., poz. 305). Zgodnie z art. 2a tejże ustawy Straż Graniczna zapobiega i przeciwdziała nielegalnej imigracji poprzez: kontrolę przestrzegania przepisów wjazdu na terytorium Polski oraz jego pobytu; rozpoznawanie i analizowanie zagrożeń migracyjnych, w tym przestępczości związanej z nielegalną imigracją; realizowanie zadań wynikających

6 Par. 3 zarządzenia nr 54 Komendanta Głównego Policji z dnia 7 października 2014 r. w sprawie organizacji, rzeczowego i miejscowego zakresu działania oraz zasad współdziałania Centralnego Biura Śledczego Policji z innymi jednostkami organizacyjnymi Policji, Dz.Urz.KGP.2014.121 z dnia 2014.10.09. 
z przepisów prawa oraz współdziałanie z innymi podmiotami właściwymi w zakresie udzielania cudzoziemcom zezwoleń na wjazd oraz pobyt.

Współpraca w zakresie zwalczania nielegalnej imigracji obywa się na poziomie krajowym - pomiędzy służbami i instytucjami szczebla centralnego i terenowego, właściwymi w zakresie bezpieczeństwa oraz na szczeblu międzynarodowym - pomiędzy wyspecjalizowanymi instytucjami i agencjami oraz służbami innych państw, których współpraca opiera się w głównej mierze na wymianie informacji oraz działaniach prewencyjnych. Polskie służby graniczne współpracują z wyspecjalizowanymi organizacjami, jak Europejski Urząd Policji (Europol) czy Międzynarodowa Organizacja Policji (Interpol).

Współpraca Straży Granicznej i Europolu opiera się na spotkaniach taktycznych, weryfikowaniu danych w Systemie Informacyjnym Europolu (EIS) oraz uczestnictwie w plikach roboczych, tj. na poziomie analitycznym, służącym rozpoznawaniu zagrożeń o wysokiej trudności wykrycia oraz sprawców najniebezpieczniejszych przestępstw. W tym celu wykorzystywane są specjalistyczne narzędzia informatyczne o właściwościach baz danych (ang. Analysis Work Files, AWF). Analityczne pliki robocze są częścią rozpracowania analitycznego (ang. Analysis Project, AP) jako procedury gromadzenia, weryfikacji, dystrybuowania informacji dotyczących spraw kryminalnych i danych wywiadowczych (Safjański, 2018, s. 110). Współpraca $z$ Interpolem opiera się na wymianie informacji dotyczącej sprawców przestępstw, identyfikacji zagrożeń poprzez korzystanie ze specjalistycznych baz danych, kanałów komunikacyjnych oraz w razie potrzeby wsparcia śledczego. Z kolei współpraca $\mathrm{z}$ agencją Frontex odbywa się w ramach spotkań taktycznych, analiz ryzyka, szkoleń, działań Zespołów Szybkiej Interwencji na Granicy, wspólnych operacji, raportowania informacji dotyczących migracji. Wymiana informacyjna na granicach zewnętrznych UE/Schengen dotyczy m.in. kradzieży pojazdów, dokumentów i ich fałszerstw, nielegalnego przekroczenia granicy, a także tożsamości osób bez dokumentów lub poszukiwanych przez wymiar sprawiedliwości. Do zakresu współdziałania należy wskazać także wspólne patrole $\mathrm{z}$ funkcjonariuszami państw sąsiadujących z Polską.

Wraz z przystąpieniem Polski od Unii Europejskiej na odcinkach granicznych wprowadzano rozwiązania dostosowujące przejścia graniczne do 
standardów unijnych, m.in. poprzez modernizację infrastruktury technicznej (Świdzińska, 2018, s. 147). Podjęte działania miały usprawnić komunikację pomiędzy służbami w wymiarze bilateralnym. Współpraca graniczna odbywa się na podstawie przyjętych umów dwustronnych między Polską i Ukrainą oraz porozumień zawieranych pomiędzy służbami granicznymi. Na odcinku granicznym polsko-ukraińskim funkcjonują dwa punkty konsultacyjne, w których prowadzona jest szybka wymiana informacji na temat zdarzeń granicznych. Współpraca Straży Granicznej i Państwowej Straży Granicznej Ukrainy ma charakter informacyjno-sprawozdawczy, realizowany poprzez organizację wspólnych Konferencji Głównych Pełnomocników Granicznych Rzeczypospolitej Polskiej i Ukrainy. W ramach spotkań omawiana jest bieżąca sytuacja graniczna oraz ocena funkcjonowania przejść granicznych (MSWiA, 2011, s. 104-105). Poza wymianą informacji statystycznych z zakresu nielegalnej imigracji rozwijana jest także współpraca operacyjno-śledcza i szkoleniowa. Straż Graniczna ze stroną ukraińską przeprowadza wspólne patrole graniczne, które realizowane są od 2011 roku. Większość $\mathrm{z}$ nich odbywa się po stronie polskiej.

\section{Podsumowanie}

Granica polsko-ukraińska jest jednym z najbardziej narażonych odcinków w kontekście nielegalnej imigracji. Sprzyjają temu czynniki geopolityczne, sytuujące Polskę jako państwo tranzytowe szlaku wschodnioeuropejskiego imigracji oraz atrakcyjne gospodarczo. Odcinek ten charakteryzuje największy ruch osobowy na granicy wschodniej Polski oraz najwyższy wskaźnik zatrzymań cudzoziemców za nielegalne przekroczenie lub usiłowanie przekroczenia granicy. W latach 2009-2019 nie odnotowano znacznego wzrostu zjawiska nielegalnej imigracji, co więcej, po 2015 roku nastąpił spadek liczby osób zatrzymywanych za nielegalne przekroczenie granicy. Ważnym aspektem systemu przeciwdziałania nielegalnej imigracji jest współpraca polskich służb odpowiedzialnych za bezpieczeństwo i ochronę granic z organizacjami międzynarodowymi oraz służbami granicznymi państw ościennych. Skupia się ona głównie na wymianie informacji, korzystaniu ze specjalistycznych baz danych oraz wspólnych działaniach prewencyjnych i dochodzeniowo-śledczych. 
Współpraca Polski i Ukrainy opiera się na przyjętych aktach prawnych, które konstytuują współpracę w zakresie nielegalnej imigracji. Praktyczny wymiar zobowiązań przejawia się we wspólnie realizowanych patrolach oraz szkoleniach. Natomiast funkcjonowanie punktów konsultacyjnych usprawnia proces wymiany informacji. Wspólne działania służb granicznych obu państw coraz skuteczniej realizują przyjęte zobowiązania. Współpraca polsko-ukraińska pomimo trwającego konfliktu we wschodniej Ukrainie nie spowodowała zahamowania w rozwoju współpracy. Analiza zmian i dynamiki ruchów ludnościowych warunkuje utrzymywanie stałej współpracy w wymiarze bilateralnym i multilateralnym państw w kontekście monitorowania trendów migracyjnych.

\section{GRZEGORZ TUTAK, MA}

Wydział Nauk Społecznych

Katolicki Uniwersytet Lubelski Jana Pawła II

Al. Racławickie 14, 20-950 Lublin

grzegorz.tutak@kul.pl

\section{Bibliografia}

\section{Monografie i artykuły naukowe}

Abraham, D. (2015). Law and Migration. W: C.B. Brettell, J.F. Hollifield (red.). Migration Theory. Talking across disciplines. New York-London: Routledge Taylor \& Francis Group.

Castles, S., Miller, M.J. (2011). Migracje we współczesnym świecie. Warszawa: Wydawnictwo Naukowe PWN.

Kacperska, E., Kacprzak, M., Kmieć, D., Król, A., Łukasiewicz, K. (2019). Migracje międzynarodowe w Europie: trendy problemy, wyzwania. Warszawa: Wydawnictwo SGGW.

Kaczmarczyk, T. (2015). Migracja - charakterystyka zjawiska. Zeszyty Naukowe Państwowej Wyższej Szkoły Zawodowej im. Witelona w Legnicy, 16, 7-15.

Klaus, W., Szulecka, M. (2018). Migracje nieudokumentowane. W: M.Lesińska, M. Okólski (red.). 25 wykładów o migracjach (367-385). Warszawa: Wydawnictwo Scholar.

Lubiewski, P. (2016). Nielegalna imigracja. Zagrożenia bezpieczeństwa, cz. 1. Szczytno: Wydawnictwo Wyższej Szkoły Policji.

Łabuz, P., Safjański, T. (2018). Zagrożenia dla bezpieczeństwa wewnętrznego Polski wynikające z napływu nielegalnych imigrantów do Unii Europejskiej - zarys problematyki. W: I. Nowicka, D. Mocarska (red.). Współczesne problemy prawa. Polityka migracyjna, t. 3. Szczytno: Wydawnictwo Wyższej Szkoły Policji. 
Marszałek-Kawa, J., Karpus, Z. (red.). (2008). Stosunki polsko-ukraińskie. Wojna i współczesność. Toruń: Wydawnictwo Adam Marszałek.

Marszałek-Kawa, J., Plecka, D., Hołub, A. (red.). (2018). Social Security. Selected Aspects. Toruń: Wydawnictwo Adam Marszałek.

Mikołajczyk, J. (1999). Straż Graniczna w zwalczaniu zorganizowanej przestępczości granicznej i korupcji. Biuletyn Centrum Europejskiego Uniwersytetu Warszawskiego, 3-4.

Okólski, M. (1998). Refleksje na temat kształtowania polityki migracyjnej w Polsce. W: K. Głąbicka, M. Okólski, D. Stola (red.). Polityka migracyjna Polski. Seria: Prace migracyjne, nr 18.

Safjański, T. (2018). Rozpracowywanie działalności terrorystycznej w ramach Europolu - uwarunkowania prawne i praktyczne. Przegląd Bezpieczeństwa Wewnętrznego, 19, 107-125.

Suduł, R. (2012-2013). Definicje i uwarunkowania nielegalnej migracji. Roczniki Wydziału Nauk Prawnych i Ekonomicznych KUL, VIII-IX, 373-394.

Świdzińska, K.J. (2018). Problem bezpieczeństwa na polsko-ukraińskiej granicy państwowej a współczesne migracje. W: M.L. Miszewski (red.). Imigranci z Ukrainy w Polsce: potrzeby i oczekiwania, reakcje społeczne, wyzwania dla bezpieczeństwa (141-152). Wrocław: Wydawnictwo Akademii Wojsk Lądowych im. gen. Tadeusza Kościuszki.

\section{Akty prawne}

Traktat między Rzecząpospolitą Polską a Ukrainą o dobrym sąsiedztwie, przyjaznych stosunkach i współpracy z 18 maja 1992 roku (Dz.U.1993 r., Nr 125, poz. 573).

Ustawa z dnia 12 grudnia 2013 r. o cudzoziemcach (Dz.U. z 2013r., poz. 1650 z poźn. zm.).

Ustawa z dnia 12 października 1990 r. o Straży Granicznej (Dz.U. z 2020 r. poz. 305).

Rozporządzenie Parlamentu Europejskiego i Rady (UE) NR 604/2013 z dnia 26 czerwca 2013 r. w sprawie ustanowienia kryteriów i mechanizmów ustalania państwa członkowskiego odpowiedzialnego za rozpatrzenie wniosku o udzielenie ochrony międzynarodowej złożonego w jednym z państw członkowskich przez obywatela państwa trzeciego lub bezpaństwowca (Dz.U. UE z 2013 r., L 180/31).

Rozporządzenie (WE) nr 562/2006 Parlamentu europejskiego i Rady z 15 marca 2006 r. ustanawiające wspólnotowy kodeks zasad regulujących przepływ osób przez granicę (Kodeks Graniczny Schengen) (Dz.U. UE z 2006 r., L 105/1).

Umowa między Rzeczpospolitą a Ukrainą o stosunkach prawnych na polsko-ukraińskiej granicy państwowej oraz wzajemnej pomocy państwowej oraz współpracy i wzajemnej pomocy w sprawach granicznych sporządzona w Kijowie dnia 12 stycznia 1993 r. (Dz.U. z 1994 r., Nr 63, poz. 267).

Umowa między Rządem Rzeczypospolitej Polskiej a Rządem Ukrainy w sprawie przejść granicznych, sporządzona w Warszawie dnia 18 maja 1992 r. (M.P. z 2003 r., Nr 37, poz. 530).

Umowa między Rządem Rzeczypospolitej Polskiej a Rządem Ukrainy o współpracy w zakresie zwalczania przestępczości zorganizowanej, sporządzona w Kijowie dnia 3 marca 1999 r. (Dz.U.z 2004 r., Nr 38, poz. 343). 
Umowa o readmisji między Wspólnotą Europejską a Ukrainą podpisaną w 2007 r. (Dz.U. z 2007 r., L 332/48).

Protokół Wykonawczy między Rządem Rzeczypospolitej Polskiej a Gabinetem Ministrów Ukrainy do Umowy o readmisji między Wspólnotą Europejską a Ukrainą, sporządzonej w Luksemburgu dnia 18 czerwca 2007 r., podpisany w Warszawie dnia 24 kwietnia 2017 r. (Dz.U. z 2019 r., poz. 48).

\section{Inne}

Frontex (2020). Migratory Routs. Pobrane z: https://frontex.europa.eu/along-eu-borders/ migratory-routes/eastern-borders-route/.

Organizacja Narodów Zjednoczonych (2013). International Migration Policies: Government Views and Priorities. Pobrane z: https://www.un.org/en/development/desa/ population/publications/policy/international-migration-policies-report-2013.asp. MSWiA (2011, 8 lipca). Raport o stanie bezpieczeństwa $w$ Polsce $w 2010$ roku. Pobrane z: https://archiwum.mswia.gov.pl/pl/aktualnosci/9258,Raport-o-stanie-bezpieczenstwa-w-Polsce-w-2010-roku.html.

MSWiA (2017, 12 października). Raport o stanie bezpieczeństwa. Pobrane z: https:// archiwumbip.mswia.gov.pl/bip/raport-o-stanie-bezpie/18405,Raport-o-stanie-bezpieczenstwa.html.

Straż Graniczna (2019, 1 lutego). Walka z przestępczością zorganizowanq i handlem ludźmi. Pobrane z: https://www.morski.strazgraniczna.pl/mor/aktualnosci/31501,Walka-z-przestepczoscia-zorganizowana-i-handlem-ludzmi.html.

Straż Graniczna. Pobrane z: https://www.strazgraniczna.pl/pl/granica/statystyki-sg/2206,Statystyki-SG.html.

Urząd do Spraw Cudzoziemców (2020). Pobrane z: https://udsc.gov.pl/statystyki/ raporty-okresowe/zestawienia-roczne/. 